\title{
EDUCORETAX
}

Volume 2 No. 1, 2022

\section{PERLAKUAN PAJAK ATAS PENGHASILAN LUAR NEGERI PADA INDONESIA INVESTMENT AUTHORITY}

\author{
Vania Rani Anissa Kurniawan ${ }^{1)}$; Ferry $\operatorname{Irawan}^{2)^{*}}$ \\ 1) anissavaniarani@gmail.com, Badan Pengawasan Keuangan dan Pembangunan \\ ${ }^{2)}$ ferry.irawan@pknstan.ac.id, Politeknik Keuangan Negara STAN \\ * penulis korespondensi
}

\begin{abstract}
Economic growth requires adequate investment both domestic and overseas. Incoming investment must be managed properly and with the principle of prudence. The Indonesia Investment Authority (INA) is established to manage investments owned by the State to be more efficient and sustainable. The purpose of this study is to analyze how the tax treatment of foreign income obtained by the Indonesia Investment Authority is. This study uses a qualitative method with a literature study approach and in-depth interviews with government official. The results of the study indicate that there is no different treatment from the perspective of taxation provisions on income earned by the Indonesia Investment Authority.
\end{abstract}

Keywords: tax treatment, Indonesia Investment Authority, foreign income

\begin{abstract}
Abstrak
Pertumbuhan ekonomi memerlukan investasi yang memadai baik dari dalam negeri maupun luar negeri. Investasi yang masuk harus dikelola dengan baik dan dengan prinsip kehati-hatian. Lembaga Pengelola Investasi (Indonesia Investment Authority) hadir untuk mengelola investasi yang dimiliki Negara agar lebih efisien dan berkelanjutan. Tujuan penelitian ini adalah untuk menganalisis bagaimana perlakuan perpajakan atas penghasilan luar negeri yang diperoleh Lembaga Pengelola Investasi. Penelitian ini menggunakan metode kualitatif dengan pendekatan studi literatur dan wawancara mendalam dengan narasumber. Hasil penelitian menunjukkan bahwa tidak ada perlakuan yang berbeda dari perspektif ketentuan perpajakan atas penghasilan yang diperoleh Lembaga Pengelola Investasi.

Kata Kunci : ketentuan perpajakan, lembaga pengelola investasi, penghasilan luar negeri
\end{abstract}

\section{PENDAHULUAN}

Perdagangan internasional berkurang sekitar 13-32\% di tahun 2020 akibat dari pandemi Covid-19. United Nations Conference on Trade and Development (UNCTAD) telah memprediksi banyak perusahaan multinasional yang akan kembali ke negara asal mereka untuk meningkatkan ketahanan rantai pasokan, fenomena tersebut dikenal dengan istilah reshoring. Fenomena tersebut didukung dengan fakta terlihat bahwa mitra-mitra perdagangan dan investasi utama Tiongkok sangat aktif dalam mendorong perusahaan mereka untuk kembali. Termasuk negara Amerika Serikat (AS) yang mempertimbangkan pemerintahnya menanggung seluruh biaya untuk melakukan relokasi. Selanjutnya, Korea Selatan juga menawarkan pinjaman relokasi lebih dari US\$3,6 miliar, dan Jepang yang mengalokasikan sebesar US\$2 miliar dalam paket bantuannya untuk perusahaan-perusahaan yang kembali (Jung, 2020; Landay, 2020; Reynolds \& Urabe, 2020).

Pengalaman dari perang dagang sebelumnya menunjukkan bahwa banyak perusahaan multinasional lebih memilih untuk memindahkan kegiatan mereka dari Tiongkok ke Asia Tenggara (The World Bank, 2018). Hampir seribu perusahaan manufaktur milik Jepang mendiversifikasi pengadaan ke luar Tiongkok. Hal tersebut juga disokong oleh pemerintah mereka yang mengalokasikan lebih dari US\$200 juta untuk mendukung rencana diversifikasi ke Asia Tenggara (Reynolds \&Urabe, 2020).

Menurut data yang terdapat pada CIA World Fact Book Tahun 2008, Indonesia merupakan perekonomian terbesar di Asia Tenggara. Pengalihan global value chain (GVC) seharusnya merupakan berita baik bagi Indonesia. Namun, Indonesia relatif dipandang tidak menarik bagi investor asing jika dibandingkan dengan negara-negara tetangga seperti Malaysia dan Thailand, karena banyaknya aturan yang menghambat investasi. 


\section{EDUCORETAX}

Volume 2 No. 1, 2022

Indeks kemudahan berbisnis (Ease of Doing Business) Indonesia sudah membaik secara signifikan sejak tahun 2014, namun belum cukup untuk mengatasi ketertinggalan dari negaranegara lain. Sangat disayangkan bahwa indikator keterbukaan terhadap investasi asing malah terus menurun sebelum dapat berbalik di tahun 2015. Kedua indikator tersebut terhambat sejak tahun 2017, padahal negara-negara tetangga malah meningkat selama periode yang sama (OECD, 2021).

Peringkat EODB Indonesia meningkat dari urutan 91 menjadi 71 dari total 190 negara. Namun, dibandingkan dengan negara-negara sesama ASEAN, Indonesia masih berada di bawah Singapura (peringkat 2), Malaysia (peringkat 24), Thailand (peringkat 26), Vietnam (peringkat 69), dan Brunei Darussalam (peringkat 57). Indonesia hanya unggul terhadap Filipina, kamboja, Laos, Myanmar, dan Timor Leste (Adesurya \& Irawan, 2018). Salah satu indikator EODB yang mengalami penurunan adalah pembayaran pajak (paying taxes). Indikator tersebut mengalami penurunan peringkat dari 104 menjadi 114 di tahun 2018 (Adesurya \& Irawan, 2018)

Pertumbuhan ekonomi Indonesia dipengaruhi oleh beberapa komponen diantaranya adalah investasi dan tenaga kerja (Nizar et al., 2013). Investasi memiliki peran penting dalam pembangunan ekonomi, pertumbuhan ekonomi tergantung pada pertumbuhan penyediaan faktor-faktor produksi yang berupa penduduk, tenaga kerja, dan akumulasi modal (Investasi) (Saptomo, 2008). Dalam ilmu ekonomi makro, salah satu komponen dari pendapatan nasional adalah investasi. Produk Domestik Bruto (PDB) atau pendapatan nasional berhubungan positif dengan investasi, PDB akan naik seiring naiknya investasi dan berlaku sebaliknya.

Dibutuhkan formulasi kebijakan ekonomi proinvestasi agar pertumbuhan ekonomi terus membaik. Untuk menumbuhkan suatu perekonomian dibutuhkan pembentukan modal sebagai penambahan stok modal. Kontinuitas pembangunan ekonomi terjamin dengan meningkatnya investasi, terserapnya lebih banyak tenaga kerja sekaligus turunnya angka kemiskinan, sehingga perbaikan tingkat kesejahteraan dapat tercapai secara menyeluruh.

Indonesia menjadi salah satu negara berkembang yang memiliki tingkat pertumbuhan ekonomi yang tinggi. Perekonomian Indonesia juga kuat dan stabil yang membuat investor merasa modalnya aman. Emerging market (pasar modal di negara berkembang) selalu berhasil menarik investor untuk masuk dan melakukan diversifikasi internasional, salah satunya Indonesia (Pratiwi, 2015).

Indonesia merupakan negara berkembang, meskipun produk domestik bruto (PDB) menunjukkan angka yang lebih tinggi dibanding negara tetangganya, Malaysia, seperti yang dimuat dalam data tingkat produk domestik bruto (PDB) Indonesia, Malaysia, dan Brasil (Gambar 1). Namun, pendapatan per kapita rendah dengan pertumbuhan penduduk yang tinggi. Badan Pusat Statistik (BPS) mencatat hasil Sensus Penduduk (SP 2020) pada September 2020 jumlah penduduk Indonesia sebesar 270,20 juta jiwa. Jumlah tersebut meningkat sebesar 32,56 juta jiwa dibandingkan hasil Sensus Penduduk (SP 2010) tahun 2010. 


\section{EDUCORETAX}

Volume 2 No. 1, 2022

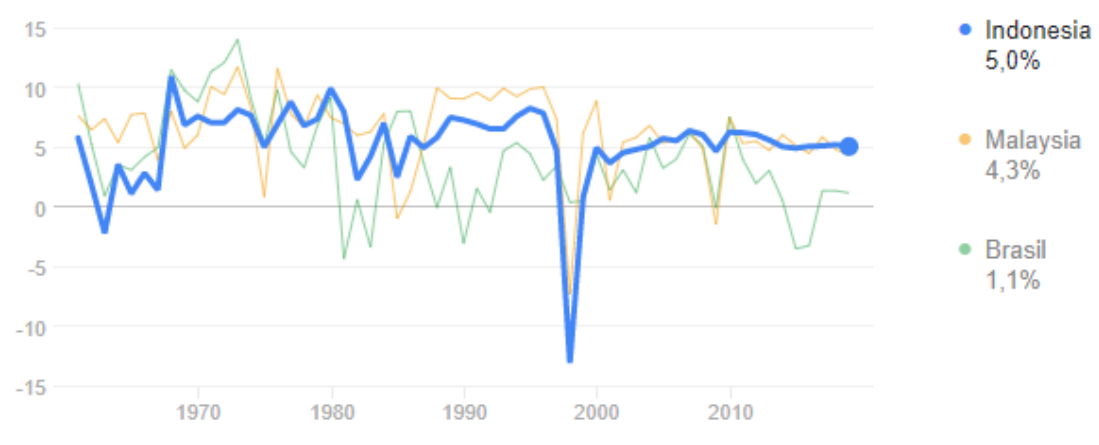

Gambar 1. Tingkat Produk Domestik Bruto (PDB) Indonesia, Malaysia, dan Brasil

Sumber: Bank Dunia, 2019

Pertumbuhan ekonomi di negara berkembang memiliki karakteristik yang berbeda dengan pasar di negara maju, sehingga akan lebih menguntungkan dalam membentuk investasi di negara berkembang (Tandelilin, 2010). Namun, banyak faktor yang menghambat kemudahan berusaha sehingga mengurangi minat investor untuk berinvestasi di Indonesia. Oleh karena itu perlu untuk mengatur dan memperbaiki sistem hukum investasi (Utomo, 2019).

Saat ini terdapat 42 ribu peraturan perundang-undangan di Indonesia. Dampaknya adalah banyak tumpang tindih peraturan baik tingkatan hierarki yang sama atau dengan peraturan di bawahnya. Oleh karena itu, Indonesia perlu menerapkan omnibus law sebagai jawaban atas permasalahan-permasalahan yang menghambat investasi di Indonesia (Suriadinata, 2019).

Penanaman modal merupakan langkah awal untuk melakukan pembangunan. Pengertian modal disini meliputi aset bentuk uang atau bentuk lain yang bukan uang yang dimiliki oleh penanam modal yang mempunyai nilai ekonomis (Winarno, 2005). Penanaman modal yang berasal dari dalam negeri disebut Penanaman Modal Dalam Negeri (PMDN) dan penanaman modal yang berasal dari luar negeri disebut Penanaman Modal Asing (PMA) (Rizky et al., 2016).

Pelaksanaan pembangunan ekonomi seperti diketahui memerlukan modal dalam jumlah yang cukup besar dan tersedia pada waktu yang tepat (Ilmar, 2006). Terbatasnya dana yang dimiliki pemerintah, untuk menggerakkan pertumbuhan ekonomi, membuat peran investasi baik secara investasi dari luar negeri (PMA) maupun dari dalam negeri (PMDN) sangat diharapkan (Ambarsari \& Purnomo, 2017).

Penanaman modal asing atau Foreign Direct Investment (FDI) memberikan dampak positif terhadap perekonomian negara tuan rumah karena melalui penanaman modal asing bisa menambah ketersediaan dana bagi negara tuan rumah (recipient country) (Athukorala, 2003). Beberapa penelitian mendukung argumentasi yang menyatakan bahwa FDI memberikan pengaruh yang besar terhadap pola perdagangan internasional dan sebagian besar FDI yang masuk ke negara-negara sedang berkembang mampu memberikan peningkatan ekspor (Kholis, 2012).

Foreign Direct Investment (FDI) atau Penanaman Modal Asing (PMA) adalah sumber paling penting dari arus sumber daya eksternal ke negara-negara berkembang setelah 1990-an dan telah menjadi pembentukan modal yang signifikan bagi negara-negara tersebut (Kumar et al., 2002). Analisis time-series di Pakistan, Tiongkok, dan Korea menunjukkan bahwa bantuan luar negeri memberi kontribusi bagi pertumbuhan, baik negara miskin maupun negara berpendapatan sedang.

Untuk menarik para penanam modal tersebut, berbagai upaya dilakukan oleh pemerintah (Arliman S. 2018). Untuk itu disusun Rancangan Undang-Undang (RUU) Omnibus law. Omnibus law Rancangan Undang-Undang (RUU) Cipta Kerja resmi disahkan menjadi 


\section{EDUCORETAX}

Volume 2 No. 1, 2022

Undang-Undang Nomor 11 Tahun 2020 pada tanggal 5 Oktober 2020 dan diterbitkan pemerintah dalam rangka menyelesaikan tumpang tindihnya regulasi dan birokrasi (Hernawati \& Suroso, 2020).

Omnibus law dibuat sebagai payung hukum untuk semua ketentuan hukum yang terkait dari sifatnya bisa lintas sektor (Prabowo et al., 2020), UU ini memuat 11 klaster pembahasan, yaitu (1) penyederhanaan perizinan, (2) persyaratan investasi, (3) ketenagakerjaan, (4) kemudahan, pemberdayaan, dan perlindungan UMKM, (5) kemudahan berusaha, (6) dukungan riset dan inovasi, (7) administrasi pemerintahan, (8) pengenaan sanksi, (9) pengadaan lahan, (10) investasi dan proyek pemerintah, dan (11) kawasan ekonomi.

Salah satu klaster yang menjadi aspek penting sehubungan dengan perekonomian Indonesia adalah klaster investasi. Pada klaster investasi, terdapat sebuah pasal yang menarik, Pasal 165 ayat (1) UU Nomor 11 Tahun 2020 tentang Cipta Kerja berbunyi, "Dalam rangka pengelolaan investasi sebagaimana dimaksud dalam Pasal 154 ayat (3) huruf b, untuk pertama kali berdasarkan Undang-Undang ini dibentuk Lembaga Pengelola Investasi." Dan Pasal 172 ayat (2) berbunyi, "Perlakuan perpajakan atas transaksi yang melibatkan Lembaga Pengelola Investasi dan/atau entitas yang dimilikinya termasuk transaksi sebagaimana yang dimaksud pada ayat (1), diatur dengan atau berdasarkan Peraturan Pemerintah." Berdasarkan hal tersebut muncul Peraturan Pemerintah sebagai turunan dari Pasal 172 ayat (2) tersebut.

Lembaga Pengelola Investasi (LPI) atau Sovereign Wealth Funds (SWF) telah didirikan oleh banyak negara. LPI selanjutnya diresmikan dengan nama Indonesia Investment Authority (INA). LPI memiliki perbedaan dengan Kementerian Investasi, meskipun sama-sama bertujuan untuk menarik investor, Kementerian Investasi memiliki tugas untuk menyinergikan investasiinvestasi yang berasal dari dalam maupun luar negeri serta melakukan investasi yang berkualitas yang sesuai dengan visi Presiden yaitu transformasi ekonomi yang meningkatkan nilai tambah dan pemerataan pertumbuhan ekonomi dari Aceh sampai ke Papua. Sementara itu, LPI bertugas untuk mengelola dana investasi baik dari dalam maupun luar negeri. Hasil dari pengelolaan dana tersebut dapat menjadi sumber pembiayaan alternatif dan mengurangi ketergantungan terhadap dana jangka pendek.

Motif negara memiliki Sovereign Wealth Funds (SWF) mungkin berbeda-beda. Sebagai cadangan jika kekayaan negara suatu saat habis sehingga tidak dapat surplus lagi dalam neraca perdagangannya atau mungkin karena ingin memiliki cadangan untuk intervensi pasar ketika kurs mata uangnya kacau atau untuk tujuan keseimbangan pembayaran luar negeri (Beck \& Fidora, 2008).

Dalam rangka penyediaan layanan dasar, peningkatan konektivitas, dan mendukung pemulihan ekonomi tahun 2021 terjadi peningkatan alokasi anggaran infrastruktur. Dimuat dalam APBN 2021, anggaran untuk infrastruktur alokasinya meningkat dari 281,1 triliun di tahun 2020 ke 417,4 triliun di tahun 2021. Untuk itu Indonesia membutuhkan LPI sebagai institusi yang dapat meningkatkan kemampuan pembiayaan pembangunan.

SWF secara tradisional dibentuk untuk menangani sejumlah masalah mikroekonomi; misalnya, memperlancar pendapatan fiskal, mengurangi 'Penyakit Belanda' atau menabung untuk generasi mendatang. Hal tersebut menyebabkan, SWF cenderung berinvestasi ke aset asing. Namun, selama beberapa tahun kedepan diharapkan melihat poliferasi 'gelombang baru' SWF dengan karakteristik yang berbeda; terutama yang berkaitan dengan struktur pendanaan mereka dan pergerakan menuju investasi dalam negeri. SWF dapat mencakup cadangan devisa, dana stabilisasi, dana pembangunan, dan perusahaan milik negara (Fry et al., 2011).

Mengenai istilah investasi, Supanca (2006) menyatakan bahwa:

Istilah investasi atau penanaman modal merupakan istilah-istilah yang dikenal, baik dalam kegiatan bisnis sehari-hari maupun dalam bahasa perundang-undangan. Istilah investasi merupakan istilah yang lebih popular dalam dunia usaha, sedangkan istilah 


\section{EDUCORETAX}

Volume 2 No. 1, 2022

penanaman modal lebih banyak digunakan dalam bahasa perundang-undangan. Namun, pada dasarnya kedua istilah tersebut mempunyai pengertian yang sama sehingga kadang-kadang digunakan secara interchangeable.

Menurut Salim dan Sutrisno (2008), investor digolongkan menjadi dua macam. Investor asing dan investor domestik. Investor asing merupakan penanam modal yang berasal dari luar negeri, sedangkan investor domestik merupakan penanam modal yang berasal dari dalam negeri.

Investasi asing berhubungan juga dengan bunga, bunga biasanya "muncul" di negara bagian di mana pembayar bunga adalah penduduk maka akan muncul penghasilan bunga (Holmes, 2007). Penghasilan bunga akan diperlakukan sebagai laba usaha jika tagihan utang yang memunculkan kewajiban pembayaran bunga itu memiliki hubungan efektif (effectively connected) dengan Badan Usaha Tetap (BUT) yang berada di negara sumber (Khurana et al., 2013). Penghasilan bunga sebagai laba usaha BUT atau penghasilan dari pekerjaan bebas dikenakan pajak penghasilan setelah memperhitungkan pengeluaran yang dapat dikurangkan dalam menghitung penghasilan kena pajak (net income basis) (Holmes, 2007).

Mengenai penghasilan bunga, Indonesia dalam Pasal 26 Undang-Undang Nomor 36 Tahun 2008 Tentang Pajak Penghasilan (UU PPh) telah mengatur mengenai pemotongan atas penghasilan yang bersumber dari Indonesia yang diterima atau diperoleh wajib pajak luar negeri selain BUT (Sovita \& Firsta, 2019). Sovereign Wealth Funds (SWF) atau Lembaga Pengelola Investasi (LPI) tentu memiliki hubungan dengan pendapatan bunga luar negeri yang pemajakannya diatur dalam Undang-Undang Pajak Penghasilan Pasal 26, maka sesuai dengan Pasal 172 ayat (2) Undang-Undang Nomor 11 Tahun 2020 akan ada peraturan yang mengatur hubungan tersebut.

Selain pendapatan bunga yang pemajakannya diatur dalam Undang-Undang Pajak Penghasilan Pasal 26, Indonesia Investment Authority (INA) juga berkaitan dengan penghasilan Wajib Pajak Dalam Negeri atau Bentuk Usaha Tetap yang berasal dari modal, penyerahan jasa, atau penyelenggara kegiatan selain telah dipotong pajak sebagaimana yang dimaksud dalam $\mathrm{PPh}$ Pasal 21. Penghasilan tersebut pemajakannya diatur dalam Pasal $23 \mathrm{UU} \mathrm{PPh}$.

Subjek pajak Pasal 23 adalah Wajib Pajak Dalam Negeri yang meliputi wajib pajak badan dalam negeri dan orang pribadi dalam negeri. Namun, Badan Usaha Tetap (BUT) yang berstatus sebagai Wajib Pajak Luar Negeri juga dapat dikategorikan sebagai subjek pajak Pasal 23 dan pemenuhan kewajiban perpajakannya dipersamakan dengan Wajib Pajak Dalam Negeri Badan yang juga merupakan subjek pajak Pasal 23.

Objek pajak penghasilan Pasal 23 diantaranya adalah dividen; bunga; royalti; hadiah, penghargaan, bonus, dan sejenisnya selain kepada Orang Pribadi; sewa dan penghasilan lain sehubungan dengan penggunaan harta, kecuali sewa tanah dan/atau bangunan; dan imbalan sehubungan dengan jasa teknik, jasa manajemen, jasa konstruksi, jasa konsultan, dan jasa lain selain jasa yang telah dipotong PPh Pasal 21. Tarif Pajak Penghasilan Pasal 23 memiliki dua jenis yaitu $15 \%$ dan $2 \%$. Tarif $15 \%$ dari jumlah bruto dividen (kecuali pembagian dividen kepada wajib pajak orang pribadi dikenakan final, bunga dan royalti) serta hadiah dan penghargaan (selain yang telah dipotong PPh Pasal 21). Tarif 2\% dari jumlah bruto untuk sewa dan penghasilan lain yang berkaitan dengan penggunaan harta, kecuali sewa tanah atau bangunan.

Pertumbuhan ekonomi Indonesia mengalami penurunan dari 5,17\% di tahun 2018 menjadi 5,02\% di tahun 2019. Badan Pusat Statistik (BPS) dalam konferensi pers di Kantor BPS, Jakarta menilai hal tersebut disebabkan oleh kinerja investasi yang menurun. INA diharapkan menjadi lembaga yang dapat menarik investasi baik dari dalam maupun luar negeri. Tujuan penelitian ini untuk menganalisis ketentuan pemajakan atas penghasilan dari luar negeri 


\section{EDUCORETAX}

Volume 2 No. 1, 2022

yang diperoleh Indonesia Investment Authority (INA). Diskusi lebih lanjut dari penelitian ini diuraikan dalam bagian kajian ustaka, metode, hasil dan pembahasan, serta penutup.

\section{KAJIAN PUSTAKA \\ Teori Dependency School}

Teori ini menggambarkan investasi asing dari negara maju merupakan hal yang negatif karena dan akan merusak ekonomi negara berkembang dalam jangka panjang. Hal ini dikarenakan adanya penetrasi dari perekonomian di luar inti sistem perekonomian nasional, oleh perusahaan besar yang berasal dari negara maju, untuk mengontrol sumber daya potensial yang seharusnya digunakan untuk pembangunan nasional.

Teori ketergantungan muncul pada akhir 1950-an sebagai tanggapan atas kekhawatiran akan kesenjangan antara negara kaya dan miskin dan bahwa pertumbuhan ekonomi di negaranegara industri maju tidak mengarah pada pertumbuhan di negara-negara miskin (Ferraro, 2008). Studi yang dilakukan oleh Raúl Prebisch, Direktur Komisi Ekonomi Perserikatan Bangsa-Bangsa untuk Amerika Latin (UNECLA) saat itu dan rekan-rekannya menyatakan bahwa kegiatan ekonomi di negara-negara maju tidak menguntungkan negara-negara miskin tetapi sering mengakibatkan tantangan ekonomi yang serius di negara-negara miskin (Ferraro, 2008). Teori ketergantungan ini mencapai puncaknya pada tahun 1970-an. Teori dependen atau ketergantungan mengungkapkan bahwa untuk dapat keluar dari ekonomi yang melemahkan negara yang sedang berkembang maka negara tersebut harus berkembang secara independen. Maksudnya, sebuah negara harus independen dari produk dan aliran modal luar negeri. Artinya, suatu negara harus berdiri dengan modalnya sendiri.

Bornschier dan Chase-Dunn (1985) menyadari sebenarnya aliran investasi asing mempunyai dampak positif dalam jangka pendek terhadap pertumbuhan ekonomi, tetapi akumulasi modal dan investasinya berdampak pada terhambatnya pertumbuhan ekonomi dalam jangka panjang. Pendapat tersebut didukung oleh Firebaugh (1998), ia menunjukkan bahwa investasi asing berdampak buruk pada negara miskin karena adanya hubungan negatif antara rasio investasi persediaan dan pertumbuhan perkapita GDP.

Bertolak belakang dengan Amerika Latin, Asia Timur dan Asia Tenggara menerapkan kebijakan aktif dalam menarik investasi asing masuk ke dalam perekonomian mereka. Akibat dari kebijakan tersebut, perekonomian di Asia Timur bertumbuh pesat pada tahun 1970 dan 1980. Peristiwa tersebut berakibat pada turunnya popularitas dari teori dependen yang kemudian menyebabkan pergeseran studi yang mengarah pada orientasi FDI (Hein, 1992).

\section{Foreign Direct Investment (FDI)}

Caves (1974) berpendapat bahwa kehadiran perusahaan multinasional di negara host lebih produktif daripada perusahaan domestik yang bergerak pada bidang yang sama serta berdampak positif terhadap kinerja perusahaan domestik. Blomstrom dan Kokko (1998) juga berpendapat bahwa perusahaan multinasional karena adanya perdagangan internasional dan investasi asing seringkali dianggap sebagai sumber utama difusi teknologi dan pertumbuhan ekonomi negara host.

Ketika suatu entitas yang berkedudukan di suatu negara memperoleh atau menetapkan kepemilikan dan kendali atas aset produktif di negara lain maka terjadi investasi asing langsung atau foreign direct investment (FDI). FDI berdampak langsung pada PDB negara tuan rumah, lapangan kerja, upah, dan kegiatan lainnya maka dari itu FDI berbeda dengan aliran modal yang lain, ia perlu membangun dan memelihara aset fisik yang menghasilkan produksi di negara tuan rumah (Blonigen, 2014).

Pengaruh adanya FDI yang masuk di Indonesia akan meningkatkan pertumbuhan ekonomi melalui peningkatan sumber daya manusia yang ahli dalam bidangnya, peningkatan 


\section{EDUCORETAX}

Volume 2 No. 1, 2022

infrastruktur, serta meningkatkan ekspor (Agma, 2015). Sehingga, dipandang perlu adanya lembaga/instansi yang dapat meningkatkan FDI yang masuk ke Indonesia.

Lembaga Pengelola Investasi (LPI) di Indonesia diresmikan dengan nama Indonesia Investment Authority (INA). INA berstatus sebagai Badan Hukum Indonesia yang sepenuhnya dimiliki oleh Pemerintah Indonesia dan bertanggung jawab kepada Presiden. Tujuan pendirian INA adalah untuk meningkatkan dan mengoptimalkan nilai Investasi yang dikelola secara jangka panjang dalam rangka mendukung pembangunan secara berkelanjutan.

Sebagai sebuah institusi, Indonesia Investment Authority (INA) memiliki dasar hukum. Dasar hukum INA adalah Undang-Undang (UU) Nomor 11 Tahun 2020 Pasal 174 ayat (4), turunan dari pasal tersebut adalah Peraturan Pemerintah (PP) 73 Tahun 2020 tentang Modal Awal Lembaga Pengelola Investasi. Kemudian Pasal 159 ayat (6) diturunkan menjadi Peraturan Pemerintah (PP) 74 Tahun 2020 tentang Lembaga Pengelola Investasi. Terakhir, Pasal 172 ayat (2) diturunkan menjadi Peraturan Pemerintah (PP) 49 Tahun 2021 tentang Perlakuan Perpajakan atas Transaksi yang Melibatkan LPI dan/atau Entitas yang Dimilikinya.

Proses bisnis merupakan serangkaian aktivitas yang disusun secara spesifik dan bergantung pada penerapan aturan bisnis yang dilakukan oleh setiap perusahaan. Proses bisnis dapat digunakan untuk menganalisis suatu organisasi. Indonesia Investment Authority (INA) juga dilakukan proses bisnis.

Berikut ini adalah proses bisnis yang dilakukan oleh INA:

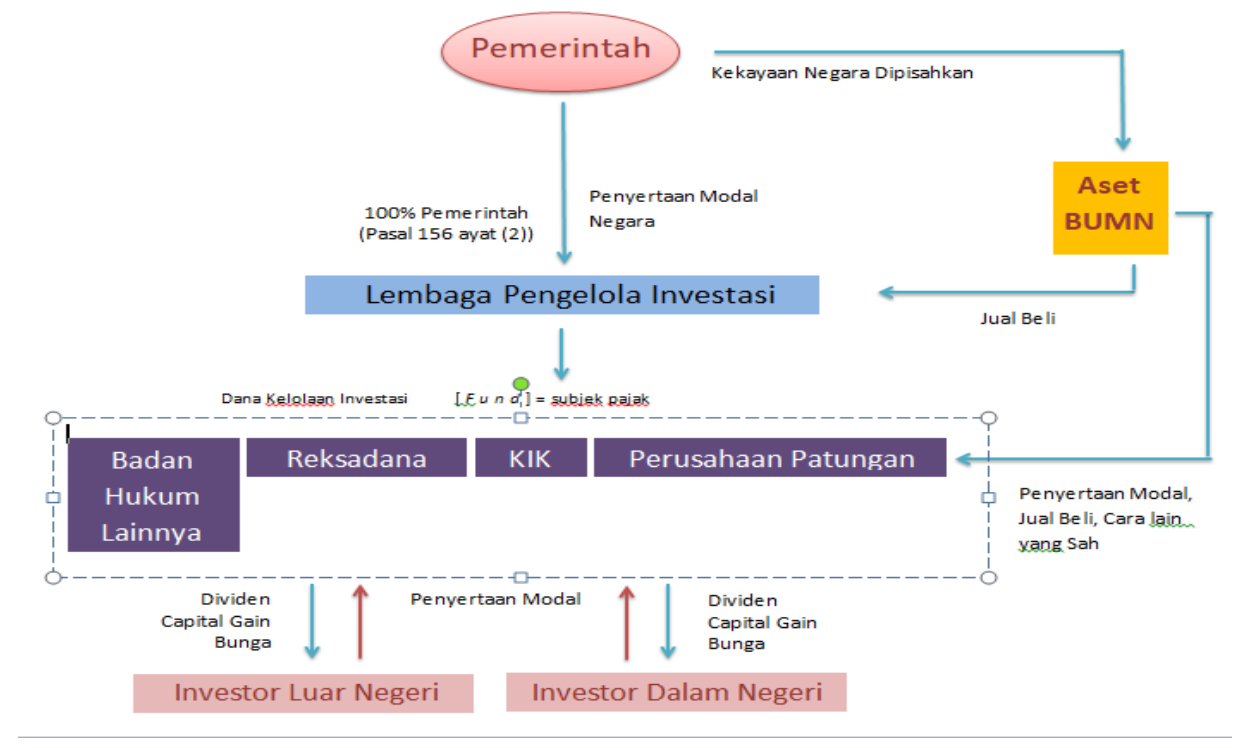

Gambar 2. Proses Bisnis LPI

Sumber: Diolah Penulis

\section{METODE}

Salah satu bagian terpenting dari penelitian adalah metode yang digunakan. Metode yang penulis gunakan adalah kualitatif dengan pendekatan studi lapangan (field research) dan studi kepustakaan.

Moleong (2021) mendefinisikan bahwa wawancara adalah percakapan dengan tujuan tertentu. Dalam metode ini peneliti dan responden secara langsung (tatap muka) untuk memperoleh informasi secara lisan dengan mendapatkan data tujuan yang bisa menjelaskan masalah penelitian. Pengambilan data dilakukan dengan mengajukan pertanyaan-pertanyaan yang telah disusun secara sistematis kepada narasumber. Narasumber dalam hal ini adalah seorang Analis Pusat Kebijakan Pendapatan Negara (PKPN) Badan Kebijakan Fiskal. Dengan 


\section{EDUCORETAX}

Volume 2 No. 1, 2022

demikian, memudahkan responden untuk menjawab dan dalam memenuhi kelengkapan data yang diharapkan oleh penulis.

Menurut Arikunto (2006) studi pustaka merupakan studi yang dilakukan dengan mempelajari sumber-sumber tertulis seperti undang-undang (UU), peraturan pemerintah (PP), peraturan menteri (PerMen), keputusan menteri (KepMen), buku, jurnal terdahulu, catatan, literatur, dan berbagai laporan yang berhubungan dengan topik penelitian yang bertujuan untuk memperoleh dasar teoritis mengenai permasalahan yang dibahas dalam penelitian ini.

\section{HASIL DAN PEMBAHASAN}

Pasal 1 ayat (2) Peraturan Pemerintah (PP) Nomor 74 Tahun 2020 menjelaskan bahwa Lembaga Pengelola Investasi atau LPI yang diresmikan dengan nama Indonesia Investment Authority adalah lembaga yang diberi kewenangan khusus (sui generis) dalam rangka pengelolaan Investasi Pemerintah Pusat sebagaimana dimaksud dalam Undang-Undang (UU) Nomor 11 Tahun 2020 tentang Cipta Kerja. INA berfungsi untuk mengelola dana pemerintah pusat yang berbentuk dana Investasi abadi. Dana Investasi abadi adalah pengelolaan Investasi dari kelebihan kekayaan negara. Selain itu, INA juga merencanakan, mengawasi dan mengendalikan Investasi. Tujuan dari pendirian Indonesia Investment Authority (INA) adalah untuk meningkatkan dan mengoptimalkan nilai Investasi yang dikelola secara jangka panjang dalam rangka mendukung pembangunan secara berkelanjutan. INA didirikan untuk meningkatkan kepercayaan investor global.

INA diberikan kewenangan yang dijelaskan pada Pasal 7 Peraturan Pemerintah (PP) Nomor 74 Tahun 2020 tentang Lembaga Pengelola Investasi. Kewenangannya meliputi: melakukan penempatan dana dalam instrumen keuangan, menjalankan kegiatan pengelolaan aset, melakukan kerja sama dengan pihak lain termasuk entitas dana perwalian (trust fund), menentukan calon mitra Investasi, memberikan dan menerima pinjaman, dan/atau menatausahakan aset. Kemudian, INA dapat melakukan kerja sama seperti yang diatur dalam Pasal 2 PP Nomor 74 Tahun 2020 tentang Lembaga Pengelola Investasi bahwa LPI dapat melakukan kerja sama dengan mitra Investasi, Manajer Investasi, BUMN, badan atau lembaga pemerintah, dan/atau entitas lainnya baik di dalam negeri maupun di luar negeri. Artinya, LPI atau INA dapat melakukan kerja sama internasional.

Seperti organisasi pada umumnya, Indonesia Investment Authority (INA) membutuhkan modal untuk melaksanakan tujuan-tujuannya. Hal tersebut dijelaskan dalam Peraturan Pemerintah (PP) Nomor 73 Tahun 2020 tentang Modal Awal Lembaga Pengelola Investasi. Pasal tersebut berbunyi, "untuk mendukung kegiatan operasional dan kegiatan investasinya INA memperoleh modal awal yang bersumber dari Anggaran Pendapatan dan Belanja Negara Tahun 2020 sebagaimana ditetapkan kembali dalam Perubahan Postur dan Rincian Anggaran Pendapatan dan Belanja Negara Tahun Anggaran 2020". INA memperoleh modal awal sebesar Rp15.000.000.000.000,00 (lima belas triliun rupiah) seperti yang disebutkan dalam Pasal 2 ayat (1) Peraturan Pemerintah (PP) Nomor 73 Tahun 2020 tentang Modal Awal Lembaga Pengelola Investasi. Modal senilai lima belas triliun rupiah itu diperoleh dalam bentuk tunai dan merupakan kekayaan negara yang dipisahkan.

Atas transaksi langsung maupun tidak langsung yang dilakukan oleh INA atau oleh entitas yang dimilikinya, akan dikenakan pajak. Seperti yang disebutkan dalam Pasal 172 ayat (2) Undang-Undang Nomor 11 Tahun 2020 tentang Cipta Kerja (Ciptaker), "Perlakuan perpajakan atas transaksi yang melibatkan Lembaga Pengelola Investasi dan/atau entitas yang dimilikinya, termasuk transaksi sebagaimana dimaksud pada ayat (1), diatur dengan atau berdasarkan Peraturan Pemerintah".

Terkait perlakuan perpajakan yang dimaksud dalam Pasal tersebut dijabarkan dengan Peraturan Pemerintah (PP) Nomor 49 Tahun 2021 tentang Perlakuan Perpajakan atas Transaksi 


\section{EDUCORETAX}

Volume 2 No. 1, 2022

yang Melibatkan LPI dan/atau Entitas Yang Dimilikinya. Pada PP tersebut terdapat fasilitas perpajakan bagi LPI atau INA dan bagi pihak ketiga, pihak ketiga yang dimaksud disini adalah investor dalam negeri dan luar negeri

Sebagai subjek pajak dalam negeri (SPDN) pada dasarnya perlakuan perpajakan pada Indonesia Investment Authority (INA) adalah sama dengan SPDN lainnya. Namun, pada Peraturan Pemerintah (PP) Nomor 49 Tahun 2021, juga dijelaskan bahwa INA mendapatkan fasilitas perpajakan atas beberapa transaksi. Pertama, atas bunga pinjaman yang diterima oleh INA dari pihak ketiga atau Dana Kelola dibebaskan dari pemotongan atau pemungutan pajak penghasilan, namun tidak termasuk bunga obligasi dalam negeri. Kedua, atas pembentukan dana cadangan wajib dapat dibebankan dengan batasan tertentu sesuai dengan yang tercantum pada Pasal 9 ayat (3) Peraturan Pemerintah (PP) Nomor 49 Tahun 2021. Yang terakhir adalah tentang Bea Perolehan Hak atas Tanah dan Bangunan (BPHTB). Atas perolehan harta berupa tanah dan/atau bangunan sebagai pengganti saham atau penyertaan modal bagi LPI, dapat dibiayakan sebagai pengurang penghasilan bruto pada tahun pajak diperolehnya tanah dan/atau bangunan.

Selain LPI selaku Subjek Pajak Dalam Negeri (SPDN), pihak ketiga juga memperoleh fasilitas perpajakan. Fasilitas untuk Subjek Pajak Luar Negeri (SPLN) adalah tentang dividen. Untuk dividen yang berasal dari pembayaran kembali karena likuidasi yang melebihi jumlah modal yang disetor atau nilai investasi awal yang diterima SPLN atas kerja sama langsung dengan LPI. Kemudian, untuk pihak ketiga subjek pajak dalam negeri (SPDN) bentuk fasilitas perpajakannya adalah untuk dividen dikecualikan dari objek Pajak Penghasilan $(\mathrm{PPh})$ berdasarkan Pasal 4 ayat (3) huruf (f). Sehingga fasilitas perpajakan yang didapat oleh pihak ketiga adalah untuk Pajak Penghasilan $(\mathrm{PPh})$ Pasal 23 adalah pajak yang dikenakan pada penghasilan atas modal, penyerahan jasa, atau hadiah dan penghargaan, selain yang telah dipotong PPh Pasal 21.

Sejalan dengan tujuan pendirian INA, terdapat peningkatan investasi baik dari dalam maupun luar negeri. Berikut adalah capaian investasi kuartal I (periode Januari - Maret) 2021.

Tabel 1. Perbandingan Capaian Investasi Kuartal I 2020 dan Kuartal I 2021

\begin{tabular}{|c|c|c|}
\hline $\begin{array}{c}\text { Capaian Kuartal I } \\
2020\end{array}$ & $\begin{array}{c}\text { Capaian Kuartal I } \\
2021\end{array}$ & $\begin{array}{c}\text { Persentase } \\
\text { Peningkatan }\end{array}$ \\
\hline Rp210,7 triliun & Rp219,7 triliun & $4,3 \%$ \\
\hline
\end{tabular}

Sumber: Data diolah dari Badan Koordinasi Penanaman Modal (2021)

Realisasi capaian investasi pada kuartal I tahun 2021 memberikan kontribusi sebesar 25,5\% dari target nasional sebesar Rp900 triliun. Capaian investasi asing (PMA) memenuhi sebesar 50,8\% dari capaian realisasi investasi kuartal I tahun 2021 sebesar Rp111,7 triliun, angka tersebut menunjukkan adanya kenaikan sebesar $14 \%$ dibandingkan capaian kuartal I tahun 2020 yaitu Rp98 triliun.

Realisasi capaian investasi pada kuartal I tahun 2021 menunjukkan bahwa terdapat pertumbuhan investasi di Indonesia. 5 negara yang memiliki kontribusi terbesar dalam pemenuhan target capaian investasi asing pada kuartal I tahun 2020 yaitu: Singapura (US\$ 2,6 miliar), R. R. Tiongkok (US\$ 1 miliar), Korea Selatan (US\$ 0,9 miliar), Hongkong (US\$ 0,8 miliar), dan untuk pertama kalinya Swiss (US\$ 0,5 miliar) masuk dalam urutan peringkat lima besar negara kontributor FDI di Indonesia. 


\section{EDUCORETAX}

Volume 2 No. 1, 2022

Menurut laporan kegiatan penanaman modal asing (PMA) untuk periode Januari Maret tahun 2021 diraih oleh sektor Industri Kendaraan Bermotor dan Alat Transportasi lain; Industri Makanan dan Minuman; Transportasi, Gudang dan Telekomunikasi; Pertambangan; dan Industri Pembuatan Logam Dasar Bukan Besi. Masuknya investasi asing menimbulkan dampak positif berupa penyerapan tenaga kerja, sehingga menekan angka pengangguran di Indonesia. Pada realisasi penyerapan tenaga kerja pada triwulan I tahun 2021 mencapai angka 311.793 orang. Jumlah tersebut berasal dari dua proyek yang sedang dijalankan oleh pemerintah, untuk proyek PMDN menyerap sebanyak 165.630 orang. Sementara itu, pada proyek PMA menyerap sebanyak 146.163 orang. Proyeksi penerimaan setoran pajak penghasilan (PPh) Pasal 23 pada tahun 2020 mencapai Rp37,84 triliun. Kementerian Keuangan menargetkan penerimaan setoran PPh Pasal 23 tumbuh sebesar 5,9\% pada tahun 2021 yaitu sebesar Rp40,22 triliun.

\section{PENUTUP}

\section{Simpulan}

INA merupakan subjek pajak dalam negeri (SPDN), pada dasarnya perlakuan perpajakannya sama dengan SPDN lainnya. Namun, pada Peraturan Pemerintah (PP) Nomor 49 Tahun 2021, juga dijelaskan bahwa INA mendapatkan fasilitas perpajakan atas beberapa transaksi. Atas bunga pinjaman yang diterima oleh INA dari pihak ketiga atau Dana Kelola dibebaskan dari pemotongan atau pemungutan pajak penghasilan, namun tidak termasuk bunga obligasi dalam negeri.

Atas pembentukan dana cadangan wajib dapat dibebankan dengan batasan tertentu sesuai dengan yang tercantum pada Pasal 9 ayat (3) Peraturan Pemerintah (PP) Nomor 49 Tahun 2021. Mengenai Bea Perolehan Hak atas Tanah dan Bangunan (BPHTB), atas perolehan harta berupa tanah dan/atau bangunan sebagai pengganti saham atau penyertaan modal bagi LPI, dapat dibiayakan. Artinya perolehan tersebut dapat dijadikan sebagai pengurang penghasilan bruto pada tahun pajak diperolehnya tanah dan/atau bangunan.

Selain LPI selaku subjek pajak dalam negeri (SPDN), pihak ketiga juga memperoleh fasilitas perpajakan. Fasilitas untuk subjek pajak luar negeri (SPLN) adalah tentang dividen. Untuk dividen yang berasal dari pembayaran kembali karena likuidasi yang melebihi jumlah modal yang disetor atau nilai investasi awal yang diterima SPLN atas kerja sama langsung dengan LPI. Tidak ada perlakuan perpajakan khusus selain mengenai Pajak Penghasilan (PPh) Pasal 23. Proyeksi penerimaan setoran PPh Pasal 23 pada tahun 2020 mencapai Rp37,84 triliun. Kementerian Keuangan menargetkan penerimaan setoran PPh Pasal 23 tumbuh sebesar 5,9\% pada tahun 2021 yaitu sebesar Rp40,22 triliun.

Saran

Untuk studi berikutnya, penulis merekomendasikan agar melakukan penelitian lebih lanjut baik secara kualitatif maupun kuantitatif terkait pendirian Indonesia Investment Authority (INA), ruang lingkup bisnis, dan aspek pemajakannya.

\section{DAFTAR PUSTAKA}

Adesurya, R., \& Irawan, F. (2018). Upaya dan Evaluasi Kebijakan Direktorat Jenderal Pajak Dalam Rangka Memperbaiki Peringkat Ease Of Doing Business Indonesia.

Agma, S. F. (2015). Peranan Foreign Direct Investment Terhadap Pertumbuhan Ekonomi Indonesia. Agma, S. (2015). (Doctoral dissertation, Universitas Brawijaya).

Ambarsari, I., \& Purnomo, D. (2017). Studi tentang penanaman modal asing di Indonesia. Jurnal Ekonomi Pembangunan: Kajian Masalah Ekonomi dan Pembangunan, 6(1), 26-47. Arikunto, S. (2006). Metodologi Penelitian. Yogyakarta: Bina Aksara. 


\section{EDUCORETAX}

Volume 2 No. 1, 2022

Arliman S, L. (2018). Penanaman Modal Asing di Sumatera Barat Berdasarkan UndangUndang Nomor 25 Tahun 2007 Tentang Penanaman Modal. Supremasi Jurnal Hukum, 1(1), 8-23.

Athukorala, P. W. (2003). The Impact of Foreign Direct Investment for Economic Growth: A Case Study in Sri Lanka. in 9th International Conference on Sri Lanka Studies (Vol. 92, pp. 1-21).

Beck, R., \& Fidora, M. (2008). The impact of sovereign wealth funds on global financial markets. Intereconomics, 43(6), 349-358.

Blomström, M., \& Kokko, A. (1996). The impact of foreign investment on host countries: a review of the empirical evidence. Policy Research Working Paper, 1745.

Blonigen, B. A., \& Piger, J. (2014). Determinants of foreign direct investment. Canadian Journal of Economics/Revue canadienne d'économique, 47(3), 775-812.

Bornschier, V., \& C. Chase-Dunn. (1985). Transnational Corporations and Underdevelopment. New York: Praeger.

Caves, R. E. (1971). International Corporations: The Industrial Economics of Foreign Investment. Economica 38: 1-27.

Central Intelligence Agency. (2008). The CIA world factbook 2009. Skyhorse Publishing Inc..

Dumairy. (1996). Perekonomian Indonesia. Jakarta: Erlangga.

Firebaugh, G. (1998). Growth Effects of Foreign and Domestic Investment. American Journal of Sociology 98(1): 105-30.

Ferraro, V. (2008). Dependency theory: An introduction. The development economics reader, 12(2), 58-64.

Fry, R., McKibbin, W. J., \& O'Brien, P. J. (Eds.). (2011). Sovereign wealth: the role of state capital in the new financial order. World Scientific.

Hein, S. (1992). Trade Strategy and the Dependency Hypothesis: A Comparison of Policy, Foreign Investment, and Economic Growth in Latin America and East Asia. Economic Development and Cultural Change 40(3):495-521.

Hernawati, R. A. S., \& Suroso, J. T. (2020). Kepastian Hukum Dalam Hukum Investasi Di Indonesia Melalui Omnibus Law. Jurnal Ilmiah MEA (Manajemen, Ekonomi, \& Akuntansi), 4(1), 392-408.

Holmes, K. (2007). International Tax Policy and Double Tax Treaties: An Introduction to Principles and Application. Amsterdam: IBFD.

Ilmar, A. (2006). Sejarah Perkembangan Penanaman Modal. Hukum Penanaman Modal di Indonesia, 2. Jakarta: K E N C A N A.

Kholis, M. (2012). Dampak Foreign Direct Investment Terhadap Pertumbuhan Ekonomi Indonesia; Studi Makroekonomi Dengan Penerapan Data Panel. Jurnal Organisasi dan Manajemen, 8(2), 111-120.

Khurana, S., \& et., a. (2013). Taxing Passive Income in the Hands of Permanent Establishment. International Taxation, 9, 640-642.

Kumar, N., \& et., al. (2002). Foreign Direct Investment, Externalities, and Economic Growth in Developing Countries: Some Empirical Explorations and Implications for WTO Negotiations on Investment. RIS Discussion Paper.

Landay, J. (2020). Full Immediate Expensing Would Lure U.S. Firms Back From China: Trump Advicer Kudlow. Reuters.

Moleong, L. J. (2021). Metodologi penelitian kualitatif. PT Remaja Rosdakarya.

Nizar, C., Hamzah, A., \& Syahnur, S. (2013). Pengaruh investasi dan tenaga kerja terhadap pertumbuhan ekonomi serta hubungannya terhadap tingkat kemiskinan di indonesia. Jurnal Ilmu Ekonomi, 1(2), 1-8. 


\section{EDUCORETAX}

Volume 2 No. 1, 2022

OECD (2021), FDI restrictiveness (indicator). doi: 10.1787/c176b7fa-en (diakses pada 3 Januari 2022)

Prabowo, A. S., Triputra, A. N., \& Junaidi, Y. (2020). Politik Hukum Omnibus Law di Indonesia. Pamator, 13(1), 1-6.

Pratiwi, N. M. (2015). Pengaruh Inflasi, Tingkat Suku Bunga SBI, Dan Nilai Tukar Terhadap Penanaman Modal Asing Dan Pertumbuhan Ekonomi Di Indonesia (Tahun 2004 Sampai Dengan Tahun 2013). Jurnal Administrasi Bisnis, 26(2), 1-9.

Reynolds, I., \& Urabe, E. (2020). Japan to Fund Firms to Shift Production Out of China. Bloomberg.

Rizky, R. L., Agustin, G., \& Mukhlis, I. (2016). Pengaruh Penanaman Modal Asing, Penanaman Modal Dalam Negeri Dan Belanja Modal Terhadap Pertumbuhan Ekonomi Provinsi Di Indonesia. Jurnal Ekonomi dan Studi Pembangunan, 8(1), 9-16.

Salim, HS., \& Sutrisno, B. (2008). Hukum Investasi di Indonesia. Jakarta: Rajawali Pers.

Saptomo, T. (2008). Pengaruh Pertumbuhan Investasi Publik, Pertumbuhan Investasi Swasta, dan Pertumbuhan Penduduk Terhadap Pertumbuhan Ekonomi Kota Semarang. Tesis MIESP-Universitas Diponegoro.

Sovita, I., \& Firsta. (2019). Analisis Perhitungan dan Pemotongan Pajak Penghasilan di Indonesia. Menara Ekonomi, 5(3), 60-72.

Supanca, I. B. R. (2006). Kerangka Hukum dan Kebijakan Investasi Langsung di Indonesia, 1. Jakarta: Ghalia Indonesia.

Suriadinata, V. (2019). Penyusunan Undang-Undang di Bidang Investasi: Kajian Pembentukan Omnibus Law di Indonesia. Jurnal Ilmu Hukum, 4(1), 115-132.

Tandelilin, E. (2010). Portofolio dan Investasi: Teori dan Aplikasi. Yogyakarta: Kanisius.

The World Bank. (2018). Indonesia Economic Quarterly 2018: Strengthening competitiveness. Utomo, P. (2019). Omnibus Law: Dalam Perspektif Hukum Responsif. Nurani Hukum, 2(1), 33-41.

Winarno, R. (2005). Penerapan Prinsip Demokrasi Ekonomi, Keadilan, dan Kepastian Hukum Dalam Hukum Penanaman Modal. Perspektif, 10(4), 385-398. 